\title{
DIGNITY
}

Dignity: A Journal of Analysis of Exploitation and Violence

\section{"A Bias Steam-Ironed into Women's Lives": A Conversation with Author Phyllis Chesler about Women and Madness, 47 Years After Publication}

Jody Raphael

jraphae2@depaul.edu

Follow this and additional works at: https://digitalcommons.uri.edu/dignity

Part of the Clinical Psychology Commons, Cognitive Psychology Commons, Health Psychology Commons, History of Gender Commons, Personality and Social Contexts Commons, Social Psychology Commons, Theory and Philosophy Commons, Women's History Commons, and the Women's Studies Commons

\section{Recommended Citation}

Raphael, Jody (2019) "'A Bias Steam-Ironed into Women's Lives": A Conversation with Author Phyllis Chesler about Women and Madness, 47 Years After Publication," Dignity: A Journal of Analysis of Exploitation and Violence: Vol. 4: Iss. 3, Article 1. https://doi.org/10.23860/dignity.2019.04.03.01

This Book Review Essay is brought to you for free and open access by DigitalCommons@URI. It has been accepted for inclusion in Dignity: A Journal of Analysis of Exploitation and Violence by an authorized editor of DigitalCommons@URI. For more information, please contact digitalcommons-group@uri.edu. 


\title{
"A Bias Steam-Ironed into Women's Lives": A Conversation with Author Phyllis Chesler about Women and Madness, 47 Years After Publication
}

\author{
Abstract \\ A conversation with Phyllis Chesler about Women and Madness, 47 years after publication, conducted by \\ Jody Raphael. Chesler discusses her motive for writing Women and Madness and its early reception. She \\ reflects on changes and lack of changes in views and treatment of women by society and the mental \\ health system in the years since its publication. Her feminist analysis now includes Islamic \\ fundamentalism, prostitution, and surrogacy, which are not always politically correct views among \\ feminists today.

\section{Keywords} \\ Phyllis Chesler, interview, Women and Madness, women, psychology, American Psychological \\ Association, review, prostitution, surrogacy

\section{Creative Commons License} \\ c) (i) $९$
}

This work is licensed under a Creative Commons Attribution-Noncommercial-No Derivative Works 4.0 License. 


\section{DIGNITY}

Volume 4, Issue 3, Article 1, 2019
A JOURNAL ON

SEXUAL EXPLOITATION

AND VIOLENCE

https://doi.org/10.23860/dignity.2019.04.03.01

"A BIAS STEAM-IRONED INTO WOMEN'S LIVES"1: A CONVERSATION WITH AUTHOR PHYLLIS CHESLER ABOUT WOMEN AND MADNESS, 47 YEARS AFTER PUBLICATION

\author{
Jody Raphael \\ DePaul University College of Law
}

\begin{abstract}
A conversation with Phyllis Chesler about Women and Madness, 47 years after publication, conducted by Jody Raphael. Chesler discusses her motive for writing Women and Madness and its early reception. She reflects on changes and lack of changes in views and treatment of women by society and the mental health system in the years since its publication. Her feminist analysis now includes Islamic fundamentalism, prostitution, and surrogacy, which are not always politically correct views among feminists today.
\end{abstract}

\title{
KEYWORDS
}

Phyllis Chesler, interview, Women and Madness, women, psychology, American Psychological Association, review, prostitution, surrogacy

$\mathrm{W}$ HEN AUTHOR Phyllis Chesler's famed book, Women and Madness, was reissued almost 50 years after its first publication last year, Dignity Editor Donna Hughes thought it would be important for the journal to mark the occasion and to interview Dr. Chesler. I first read the work when I was the same age of its author, at the height of the second wave of feminism in the U.S. Reading it today demonstrated to me what I had missed then-its thorough and maddening description of patriarchy and our culture's efforts to maintain it. And it seemed to me that not much had changed since then. I welcomed the opportunity to find out if Phyllis Chesler agreed with me.

It all started at the American Psychological Association (APA) convention in 1970. Phyllis Chesler, who had co-founded the Association for Women in Psychology, made a demand of APA members for one million dollars in reparations on behalf of women who had not been helped by the mental health professions, but who in fact had been further abused. Chesler writes that women were:

Punitively labeled, overly tranquilized, sexually seduced while in treatment, hospitalized against their wills, given shock therapy, lobotomized, and above all, unnecessarily described as too aggressive, promiscuous, depressed, ugly, old, angry, fat, or incurable (Chesler, 2018, p. 3).

${ }^{1}$ Adrienne Rich writing about Women and Madness and the embedded views of women in 1972. 
The mostly 2,000 men in the audience, laughed, some loudly, some nervously. Afterwards colleagues told Chesler of the jokes made privately about her "penis envy."

From Chesler's experience came a book called Women and Madness, written when she was 31 years of age, and which appeared one year later in 1972. Since then it has been continuously in print, first at Doubleday, then at Avon, Harcourt, Brace, Jovanovich, and Four Walls Eight Windows, followed by Palgrave Macmillan, which commissioned a new introduction with its 2005 publication. Chesler's 2005 publisher wanted the book updated, but only small, select parts were altered, as Chesler explains she was ambivalent about revising what was now an historical text. In September 2018, Lawrence Hill Books, an imprint of Chicago Review Press, brought out the 2005 edition again, in paperback, and, for the first time, as an audio and an e-book.

Chesler has been told that three million copies have been sold in the almost 50 years of the book's existence, and it has been translated into numerous foreign languages. Neither the 2005 nor the 2018 edition has received new book reviews or author interviews. This lack of attention is a bit different from the book's initial reception. Then it received a favorable, front-page review by feminist poet Adrienne Rich in the New York Times Book Review in 1972 which probably "made" the book. It was also positively mentioned in other publications. However, the book was "savaged," in Chesler's words, by reviewers both male and female, who described the author as "strident" and "man-hating." In The Village Voice (1973), for example, a review by a professor at New York University's postdoctoral program in psychotherapy and psychoanalysis, and the husband of the book's negative reviewer in The Partisan Review, wrote that Chesler "favors[s] lesbianism as a definitive solution to the problem of gender differences;" "equates psychosis and social heroism;" and views Madness as a form of positive, militant feminism." Both husband and wife, Chesler thinks, saw Chesler as promoting a homosexual Amazon community.

In a nutshell, the book's thesis is that women who are labeled "mad" and medically treated, or even institutionalized, are either "acting out the devalued female role or the total or partial rejection of one's own sex-role stereotype" (p. 116). "Women who reject or are ambivalent about the female role frighten both themselves and society so much so that their ostracism and self-destructiveness probably begin very early. Such women are also assured of a psychiatric label...” (p. 116). Using her thesis Chesler describes the lives of writers Zelda Fitzgerald, Sylvia Plath, and Virginia Woolf, the latter two who committed suicide, an analysis worth the price of the book alone.

For Chesler, "madness" stems from the continual sacrifices women make, many of which involve childbearing. Her summary is worth quoting in full:

Women are impaled on the cross of self-sacrifice. Unlike men, they are categorically denied the experience of cultural supremacy and individuality. In different ways, some women are driven mad by this fact. Their madness is treated in such a way as to turn it into another form of self-sacrifice. Such madness is, in a sense, an intense experience of female sexual and cultural castration and a doomed search for potency (p. 91). 
Newly published letters of Sylvia Plath (Plath, 2018) validate Chesler's thesis, made so many years ago, about this particular author. Clearly, the letters sent at the end of her life dramatically demonstrate that Plath was stuck between her desire to fulfill her societal-designated roles of wife, mother, and uber homemaker, (which her husband thwarted by his repeated philandering and leaving her for another woman), and her burning need to create poetry and prose-one of the issues that contributed to her eventual suicide.

Using extensive and damning quotes from influential psychoanalysts from Freud to Reich, Laing, and Szasz, Chesler demonstrates how the psychiatric and psychological profession, still mostly men, medicalizes women suffering from the ravages of patriarchy, and inappropriately "treats" them. But the work is not just an indictment of the medical and psychological profession. Very quickly it rolls out a powerful description of patriarchy and its effects, where mental health is used as a weapon by men to preserve their domination over women. It makes for a harsh picture. It is also an absolutely amazing achievement for a 31-year-old, which paved the way for numerous other feminists like Susan Brownmiller and Mary Daly (Spender, 1985). And shockingly, her depiction of that patriarchal culture, as written in 1972, remains as valid today as it was then.

Noteworthy are the instances in which Chesler shows incredible prescience. So many years ago, she had understood the institution of prostitution to be an important part of patriarchy. She notes that the majority of women in prostitution have fled incestuous and abusive families and turn to alcohol and drugs in order to endure lives "in which they are repeatedly the victims of profound psychological, physical, and sexual violence" (p. 136). Now, she explains, the male demand for sex with children has grown into a large industry, which involves kidnapping or luring children under false pretenses into the sex trade industry. And, after all this, the girls and women are degraded and punished by society: "It is their humiliation through their bodies- as much as their bodies-which is being purchased" (p. 159). Although in advanced capitalist society, people sell most things-time, skills, physical labor-she believes that prostitution may exist in a separate category from these other sales of self because of the humiliation imposed on them. Prostitution always

signifies the relatively powerless position of women and their widespread sexual repression. It usually also signifies their exclusion from or subordination within the economic, political, religious, and military systems (p. 193).

Chesler is also not afraid to take on the gay rights lobby, which, she says, contributes to our phallic-centric culture. One example of the harm to women are gay male rights organizations advocating for state legalization of surrogacy so that gay men may purchase and raise genetic children- laws that would allow purchase or rental of women's bodies, only to discard them.

Although her focus is on patriarchy, Chesler does not write to shame men. The book is a call to women to make men reform (Spender, 1985). She feels that women bear some complicity in their disempowerment by accepting the phallic-centric world and embracing the many required self-sacrifices within it. She retains the original insights of second wave feminism that women must be their own salvation. Recently in the U.S. we have seen frustrating examples of this-women not using the power they have by refusing to vote for women for high office, and many of the women in the U.S. Senate supporting Presidential nominees accused of rape, 
sexual harassment, and making misogynistic comments. Women's primary egoidentity, Chesler writes, is rooted in concern for limited and specific others and for what pleases a few men: "Woman's ego-identity must somehow shift and be moored upon what is necessary for her own survival as a strong individual" ( $p$. 347). She continues:

Those women involved in such an ego-transformation would, by necessity, withdraw from all human interactions which are not extremely supportive of their survival and achievement of individual power. Other ways of saying this might be: the growth in women of a greater psychological investment in female rather than in male survival, power and pleasure; women must withdraw from patriarchal hatred of women's bodies and from our addiction to a relationship at any price (p. 348).

To be clear, Chesler explains, this might mean withdrawal from toxic womanhating women as well as from men. Chesler did not rule out relationships with supportive men.

Now a word about Chesler's "take no prisoners" style. Even favorable reviewer Adrienne Rich (1972) found Chesler's uncompromising pronouncements slightly off-putting. Although appreciating Chesler's personal force and power, she writes that the book needs editing because her thoughts appear to be random and disorganized: "Parts of an argument get scattered through the book, or too many insights flood too quickly." However, the unending avalanche of observations creates the emotional response in the reader Chesler is seeking. Although one commentator writes that Chesler is angry, and undoubtedly intends to make women readers angry too (Spender, 1985), Chesler objects to the term "angry," because strong feminist analyses are routinely dismissed as "too angry." Feminist writer Dale Spender, though, perfectly captures Chesler's approach:

Women and Madness is too much! It is too bold, too bald, too bare. It strips patriarchy down to its essence and leaves little room for rationalisation. It paints a picture which is not at all pleasant: that is why I think many members of society prefer to look the other way (Spender, 1985, p. 154).

In all, Chesler has published 18 books and thousands of articles. She says that, with one or two exceptions, none of her $21^{\text {st }}$ century books has been reviewed in the mainstream media-an indication. Perhaps Chesler's uncompromising positions and her hard-hitting style make people uncomfortable. There are, however, other reasons for the neglect, beyond the scope of this article. Later works deal with issues in a way not considered politically correct. She is criticized for being "Islamophobic" for her work on the honor killing (femicide) of Muslim women, and she raises concerns about certain feminists in her book Woman's Inhumanity to Women.

In her new introduction to the 2005 reprint, Chesler answered the question, "What has changed since I wrote this book?" Her response: "Too little-and quite a lot" (p. 10). In the intervening years, she writes, we have learned a good bit about the genetic and chemical basis of mental illness and how drugs can alleviate symptoms, and how trauma and violence produce a host of symptoms, often leading to self-medication. But she claims that continuing clinical bias affects women: women are still wrongfully diagnosed and medicated; women who allege rape, incest, battery, sex discrimination, or sexual harassment are inappropriately ordered 
into therapy or diagnostically pathologized at trial; and psychotherapist-patient sexual abuse still exists.

I was curious to learn, from Chesler herself, whether she thought anything had improved since 2005, the date of her previous summation. We undertook a brief e-mail interview in late spring 2019.

Noting a current anti-feminist backlash, Chesler, you will find, is not currently optimistic. Our conversation, lightly edited, follows, but it is no substitute for the book itself, which very much merits a first reading or a re-read.

Q. In the book you give statistics about the gendered nature of the psychiatric/psychological profession. Have there been improvements?

Chesler: I believe that there are more feminist-oriented therapists than existed in the 1960s and even in the 1970s. But today, certainly from the 1990s on, "mood disorders" are treated with drugs, not with talking therapy, which is far too expensive for most people, especially poor women, who have no access to quality, feminist therapy.

Q. How would you gauge the changes in the profession between 1972 and now in terms of recognizing the sources and causes of women's problems?

Chesler: I cannot answer this question based on research, surveys, or even clinical data. There may be valid information out there on these questions, but I am not in command of it. My impressions, from afar, are as follows:

Wrongful diagnoses and medication continue and may be strictly class and race based-there is no medical or good insurance coverage for quality mental health care for most people;

The police still mistreat rape victims and do not follow through, but there has been enough research, advocacy, and information about the nature of rape, incest, and sexual harassment to somewhat, hopefully lessen patriarchal views on this subject. However, I fear that what we see on Law and Order: Special Victims does not mirror reality;

There is now a body of writing by feminist women of color, but only feminist therapists and feminist therapists of color are probably familiar with it. I doubt that such work is routinely part of the medial or graduate school curriculum. I doubt that Women and Madness has been routinely taught at these levels. Thus, most white male professionals, despite exceptions, may think and act just as their non-mental health male counterparts do, as may non-feminist female mental health professionals; and

Abuse of power by therapists still exists and is still denied. There are many studies out there that address this. I can only guesstimate, and from afar, as to how much less of such abuse there might be. However, women rendered vulnerable by childhood sexual and physical abuse would still remain vulnerable to the continuation of such abuse when seeking help from a presumed protector. And in terms of the \#MeToo movement, we cannot doubt that predators in all fields are continuing whatever abuse they can get away with. We are also living at a moment in history when rape has become a weapon-not merely a spoil of war- and when sexual slavery and human trafficking have both become more visible even as they have increased. 
Historically, rape was a spoil of war. It would be a spoil, something soldiers did, got away with doing, it was expected, not planned. The difference is that genocidal/gender cleansing gang rape is planned, systematic, and is yet another weapon of war. Academic studies have begun to appear about the gang rape of Christian Armenian girls and women by Ottoman-era Turkish Muslims; the repeated, systematic and very public gang-rape of Jewish women in the Ukraine (1918-1921) by successive waves of warring soldiers, neighbors, and pogramciks; ${ }^{2}$ the repeated and systematic gang rape of Bangladeshi women by Pakistani soldiers in 1971; the repeated and systematic gang rape and kidnapping into sexual and domestic slavery of North African Muslim women in the Maghreb; and Cristian and Muslim women in Bosnia and Serbia, aka the former Yugoslavia; and the repeated and pubic gang rape of girls and women in Rwanda, Sudan, and Nigeria. I describe this phenomenon as "gender cleansing" because the women are usually driven out of their minds, become suicidally depressed, and risk being honor killed by their families who are shamed.

Q. In the book you write that women are labeled as mentally ill, while men are called criminals. Has this changed, what with more women imprisoned than ever before?

Chesler: [When I last researched this] women received heavier sentences for lighter crimes than men. There were fewer recreational and educational opportunities for women than for men in prison; battered women who killed in self-defense often got life sentences. Fewer if any family members remained in contact with women in prison than with men in prison. I doubt this has changed but I have not done any recent research on this. What is also clear now is that women are more often imprisoned for low level drug offenses and less often for violent crimes than their male counterparts. Also clear: women who have been their child's primary caretaker lose their children to foster care. Male prisoners who have never been primary caretakers, bear no shame if they are now absent due to a jail sentenceand unlike women, someone in their family, a mother, a girlfriend, etc. will raise their child and bring him (her) to visit. Not so for women. Given all this, what's changed is that more women are in jail and prison than in the 1980s. No one in prison has access to quality mental health care although male batterers have mandated education about battering. Battered women have groups in prison as well. Imprisoned women are seen as drug addicts, prostitutes, and criminals. I doubt they are seen as incest victims whose violent physical and sexual abuse has led to life-long trauma and an inability to make good choices.

Historically, many of the alleged "hysterics" whom Breuer and Freud treated and learned from were very poor women, often prostituted women. The fact that they had been sexually and physically traumatized in childhood and thereafter, battered and demeaned by countless others, was never recognized or given proper weight. The fact that they were preyed upon by men, were the victims of great violence, and were scorned by non-prostituted women, was not recognized either. Now, in a feminist and "post-feminist" era we better understand that incest and rape lead to symptoms, not of mental illness, but akin to those of torture victims. Thus, eating disorders, drug addiction, flashbacks, insomnia, nightmares, hypervigilance, and so on are probably evidence of torture, not necessarily of an intrinsic neuro-chemical imbalance. Add to this the sorrows of racism and poverty and one

${ }^{2}$ A Yiddish term for perpetrators of violent, genocidal attacks on Jews known as pogroms. 
can begin to see that most (not all, most) jailed women need psychological help, not punishment.

Q. Would you say that recently strides have been made in sexual assault and sexual harassment, due to the \#MeToo movement? As for prostitution wouldn't you agree we have taken steps backwards, with some feminist groups seeking to normalize the sex trade industry by pushing for decriminalization of the entire industry?

Chesler: I do not think that the \#MeToo movement has as yet translated into the abolition of sexual harassment, incest, and rape. In fact, there may be something of a continued backlash afoot. Women have been increasingly disappeared. The face of patriarchy is staring us down in terms of the movements to legalize/decriminalize prostitution; legalize surrogacy; outlaw or restrict abortion; the obsession with transgender male-to-female victimization; the disappearance of "women" from women's studies which has morphed into gender studies and then into LGBTQIA [Lesbian, Gay, Bisexual, Transgender, Queer, Inter-sex, and Asexual] studies; and in the massive increase and normalization of pornography which we may see very clearly in how celebrities dress as half-naked "hookers." And this style is seen as fashionable and copied by teenage girls. In short, radical abolitionist feminism is losing on every front.

Q. I was struck by your statement in the book that homosexuality in a patriarchal society is an expression of phallic worship. Do you think the gay rights movement is having a negative impact on issues such as rape and prostitution?

Chesler: Homosocial culture is, by definition, anti-woman. Both gay and straight men, like women, value men above women. This might be true even though they remain dependent on women who "know their place" and whose support they rely upon. Homosexuality simply bumps the preference up a bit and has, in our time led to gay male couples funding a movement to legalize surrogacy. This means that a five-minute donation of sperm is considered equal to a painful, and medically risky donation of an egg and to nine months of pregnancy and labor on the part of the rapidly disappeared birthmother and to the evisceration of motherhood. This is also, of course, big business at work. Selling children is highly profitable for doctors and lawyers, especially to infertile women and to wealthy and celebrity women who do not wish to be pregnant Many lesbians were involved in AIDS-related projects. How many gay men marched for abortion? Or for uterine or ovarian cancer? Just wondering.

\section{Q. Do women have more power than they use?}

Chesler: Women still do not vote for women-although more do so. Women still do not trust women as much as they trust men. Women are no kinder to other women than men are-only betrayal at female hands seems to hurt more. Women still expect other women to be their fairy godmothers and when we fail at one task, we become evil stepmothers who are then demonized and ostracized by small cliques of women.

\section{Q. In 50 years, how much, if any, has patriarchy been dismantled?}

Chesler: More women have entered formerly all-male professions. Lesbian mothers do not lose custody for that reason alone. To some small extent, some men are sharing more of the burdens of child raising. But glass or rather steel ceilings remain in place. Sexual harassment, rape, and coerced sex remain a fact of life for 
the women at work and whistleblowers are punished, whether they are marines or saleswomen in jewelry stores or women who work in the mines. Both pornography and prostitution have increased and have had greater influence over the coming generations. Radical abolitionist feminists did not triumph in the academy. Recently I received a telephone call from this book's audio reader, who congratulated me for having written such a timely, relevant, and mind-blowing work. Although I appreciated the comment, her words depressed me. I had hoped that womankind might have evolved a bit more-after all, I was writing this book almost 50 years ago.

\section{Q: How do you feel about your public reception?}

Chesler: Patriarchal habits of mind, in both men and women, as well as the realities of competition, have meant that I have never once been asked to address a college graduation ceremony. I have never once received an honorary degree. Like so many worthy others, I have not been included in the Women's Hall of Fame. I was never allowed to teach graduate students at City University of New York (CUNY), except once, for one semester, at John Jay where I had a master degree class of mainly police officers and domestic violence shelter workers to whom I taught forensic psychology. I have never once received another offer of a tenured professorship at another university. It took me 22 years to be promoted to full professor at CUNY and only after major fights and appeals. And, with one or two exceptions, none of my $21^{\text {st }}$ century books has been reviewed in the mainstream media. Please feel free to draw your own conclusions about what this means.

Although these are sobering points, I have been exceptionally lucky as a writer. I would not have been this fortunate had there not been an active and radical feminist movement alive in the world. Women embraced my ideas and bought my work. Publishers have kept me in print for nearly 50 years. This is great good luck. My work has been translated into many European languages and into Japanese, Chinese, Korean, and Hebrew. The fact that I always had to work many other paid jobs to support the vice of writing and of activism is both important but beside the point. Great writers have often had to self-publish and their work was rarely or only negatively reviewed. Still, I have had a significant reach, and my work has been influential in changing how women and "madness" are viewed and treated.

\section{AUTHOR BIOGRAPHY}

Jody Raphael is Senior Research Fellow, Schiller DuCanto \& Fleck Law Center, DePaul University College of Law, Chicago, Illinois. She has been researching in the areas of prostitution and human trafficking since 2001, and is the author of four books on violence against women with particular emphasis on denial. Her latest book is Rape Is Rape: How Denial, Distortions, and Victim Blaming Are Fueling a Hidden Acquaintance Rape Crisis (Chicago Review Press paperback).

\section{RECOMMENDED CITATION}

Raphael, Jody. (2019). “A bias steam-ironed into women's lives”: A conversation with author Phyllis Chesler about Women and Madness 47 years after publication. Dignity: A Journal of Sexual Exploitation and Violence. Vol. 4, Issue 3, Article 1.

https://doi.org/10.23860/dignity.2019.04.03.01 Available at http://digitalcommons.uri.edu/dignity/vol4/iss3/1. 


\section{REFERENCES}

Chesler, P. (2018). Women and madness. Chicago: Lawrence Hill Books.

Plath, S. (2018). The letters of Sylvia Plath, Vol. 2: 1956-1963. New York: Harper.

Rich, A. (1972, December 31). Women and madness. The New York Times Book Review. Retrieved from www.nytimes.com/1972/12/31/archives/women-and-madnessby-phyllis-chesler-illustrated-359-pp-new-york.html/

Spender, D. (1985). For the record: The making and meaning of feminist knowledge. London: The Women's Press Limited. 